Journal of Nepal Geological Society, 2019, vol. 59, pp. 1-8

DOI: https://doi.org/103126/jngs.v59i0.24981

\title{
Mineralogy, geochemistry and economic potentialities of heavy mineral sand resources of Bangladesh
}

\author{
Eunuse Akon \\ Consultant, Institute of Mining, Mineralogy and Metallurgy (IMMM), BCSIR, Joypurhat, Bangladesh
}

Email: eunus.akon@gmail.com

\begin{abstract}
Heavy mineral sand deposits are the important mineral resources of Bangladesh. Systematic mineral exploration activities carried out in the south eastern coastal belt of Bangladesh were successful to discover seventeen heavy mineral sand (HMS) deposits in the coastal beach and off-shore islands. Mineralogy, geochemistry and mineral processing characteristics of the heavy mineral sands and their economic potentialities are presented in the present paper. On an average, HMS deposits contain $23 \%$ total heavy minerals. In heavy fraction, average weight percentage of the economic minerals is: zircon $4.20 \%$, rutile $2.04 \%$, ilmenite $26.03 \%$, garnet $6.45 \%$, kyanite $3.92 \%$, leucoxene $2.30 \%$, magnetite $1.87 \%$ and monazite $0.31 \%$; and the average weight percentage of other non-economic heavy minerals is $53.88 \%$. Heavy mineral sand deposits altogether contain 1.76 million tons of economically important heavy minerals which are: ilmenite (1,025,000 tonnes), garnet (223,000 tons), zircon (158,000 tonnes), leucoxene ( 97,000 tons), kyanite (91,000 tons), rutile (70,000 tons), magnetite (81,000 tonnes) and monazite (17,000 tonnes). Occurrence of large amount of economic heavy minerals in the sand bars of Brahmaputra-Jamuna River has been reported by some recent studies. On an average, total heavy mineral percentage of the Brahmaputra-Jamuna sand bars is around $8.92 \%$. Mineral sand processing on the bulk samples has been carried out at the pilot plant comprising gravity, magnetic and electrostatic separators to characterize the separation characteristics of individual economic heavy minerals. Geochemical studies on the separated heavy minerals show that $\mathrm{TiO}_{2}$ in rutile is around $90 \%$ and $\mathrm{ZrO}_{2}$ in zircon is around $65 \%$, which are quite satisfactory in respect of commercial grade. Ilmenite contains low level of titanium dioxide $\left(\mathrm{TiO}_{2}-43 \%\right)$ and higher level of chromium, manganese and iron. Beneficiation and upgrading of ilmenite will be required to make it a marketable commodity. Valuable minerals present in the heavy mineral sand deposits of Bangladesh need to be mined sustainably and utilized for the benefit of the country.
\end{abstract}

Keywords: Bangladesh, Heavy Minerals, Geochemistry, Reserve, Benefication

Paper Received: 24 Feb 2019

Paper Accepted: 6 Jun 2019

\section{INTRODUCTION}

Bangladesh Atomic Energy Commission (BAEC) has been entrusted with the responsibility of exploration and exploitation of economic heavy mineral sands. The valuable minerals in mineral sands are predominantly ilmenite, rutile, zircon and their weathered equivalents. These heavy minerals occur in very low concentrations in a variety of igneous and metamorphic rocks, but being chemically and physically resistant to weathering, and having comparatively high specific gravity, they tend to accumulate in placer deposits along coastal shorelines/beaches or in river channels. The physicochemical behavior of provenance rocks, drainage pattern and climatic factors played prominent role in the supply of material for concentration along favorable places. Once liberated from parent rock, placer minerals get concentrated by hydraulic processes primarily because of density contrasts. Coastal processes (wave velocity, long shore currents and wind speed) have their effects in littoral transport, sorting and deposition of placer minerals. A breaking wave takes all the foreshore minerals to the beach but the backwash carries only the lighter minerals back to the sea leaving behind the heavy minerals. Repeated action of waves results in sorting and the concentration of heavy minerals in beach placer deposit. After the concentration is over, action of the wind further enriches the concentration by blowing away the finer and the lighter sand particles, thus leaving the in-situ deposit rich in heavy minerals. Emergence and submergence of the coast during geological past also affected the beach placer formation. Apart from these, other factors such as coastal geomorphology, neo-tectonics and continental shelf morphology have contributed for the formation of heavy mineral sand deposits. Beaches are favorable sites for light heavy minerals e. g., ilmenite, magnetite, rutile, zircon, etc. whose specific gravity ranges in between 4.2 to 6 . These heavy minerals are used in different industries through physical and chemical processing and they have fairly high demands at home and abroad; and for these reasons their exploitation and marketing can contribute considerably towards the growth of national economy.

Bangladesh Atomic Energy Commission through its Beach Sand Mineral Exploitation Centre and Nuclear Minerals Unit has been carrying out exploration activities for heavy mineral sands in the south eastern and southern coastal stretches 


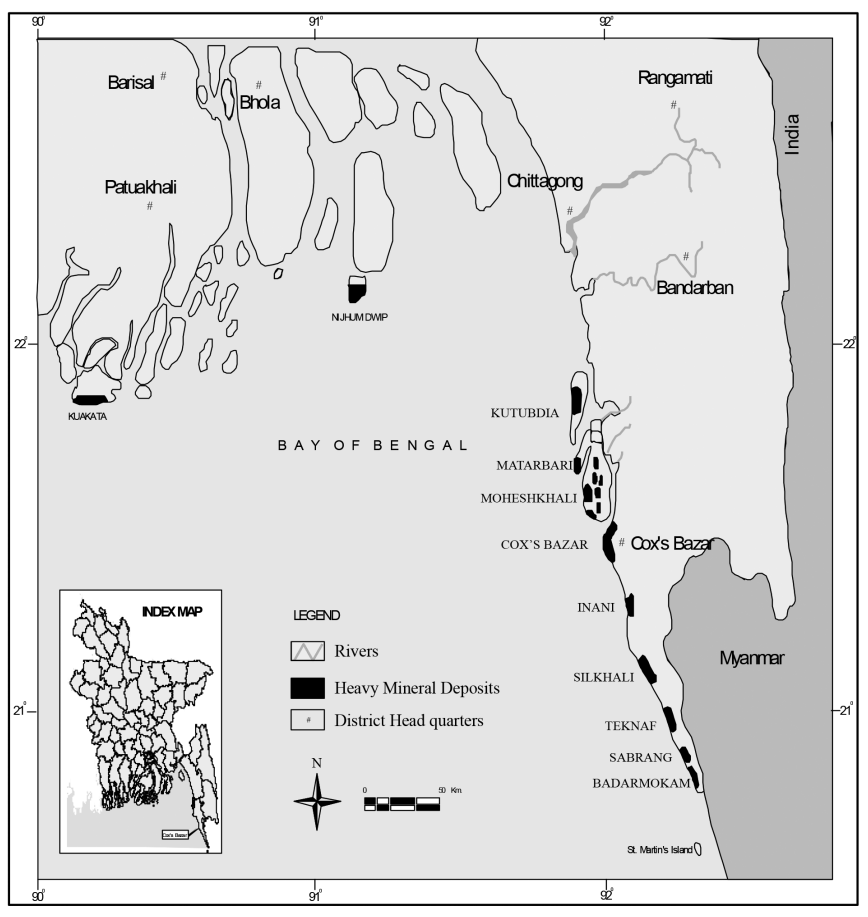

Fig. 1: Location of heavy mineral deposits discovered by BAEC

of Bangladesh for more than three decades. A good number of articles have been published on the mineral sand investigations (Howarth et al., 1977; Macdonald, 1976; Biswas, 1983; Akon and Hossain, 2004; Kabir et al., 2010; Akon, 2015;). Premier Minerals Limited is also engaged for exploration and development of heavy mineral resources since 2007. This paper is an overview of the exploration activities carried out on mineral sand deposits of Bangladesh. The results and findings of the exploration activities are presented here with.

\section{METHODS}

Systematic survey was conducted by fixing a baseline, parallel to the long direction of the deposits, whose general outline was recognized by its topography and occurrence of black sands on the surface. A series of parallel lines were laid out perpendicular to the base line as grid lines. A full-scale drilling program was carried out with a general grid pattern of $152 \mathrm{~m}$ intervals between lines and hole spacing of $8 \mathrm{~m}$ along the lines. Heavy mineral \% was determined using heavy liquid Bromoform $\left(\mathrm{CHBr}_{3} ; 2.89\right.$ sp.gr.) and Methylene iodide (di-ido methane, $3.3 \mathrm{sp}$. gr.). Mineralogical studies were carried out using, binocular microscope, petrological and ore microscope. Magnetic separation of certain heavy fraction was performed by running it through the Frantz Isodynamic Separator in different ampere conditions $(0.07,0.2,0.4,0.5,0.7,1.0,1.5$, and $2.0 \mathrm{~A}$ ) on the basis of magnetic susceptibility. Bulk sample and different sample fractions got by heavy liquid and isodynamic separation were used for X-RD analyses. Selected samples separated in the laboratory and in the pilot plant tests have been chemically analyzed using XRF. Mineral processing of the bulk sample from heavy mineral deposit has been carried out in the pilot plant at Cox's Bazar consisting of gravity, magnetic and electrostatic/electromagnetic separators. Mineral separation was done by taking advantage of the differences in properties like specific gravity, magnetic susceptibility and electrical conductivity. Radiation dose was also measured using gamma survey meter.

\section{RESULTS AND DISCUSSIONS}

As a result of last three decades long exploration activities carried out by Bangladesh Atomic Energy Commission (BAEC) seventeen heavy mineral deposits have been discovered in the south eastern coastal belt of Bangladesh (Fig. 1). Prospective areas for the heavy minerals in Bangladesh are shown in Fig. 2. Among the discovered mineral sand deposits, six deposits are located along the Cox's Bazar-Teknaf coast (Badarmokam, Sabrang, Teknaf, Silkhali, Inani, and Coxs Bazar), seven deposits in Moheskhali Island, one deposit in Matarbari Island, one deposit in Kutubdia Island; and two are located in the southern coast (Nijhum Dwip of Hatia and Kuakata of Patuakhali). These deposits range from 152-3050 metre in length, 15-305 metre in width and 1-4.5 metre in thickness. They occur as low linear ridges and dunes (Fig. 3). Some deposits extend up to a distance

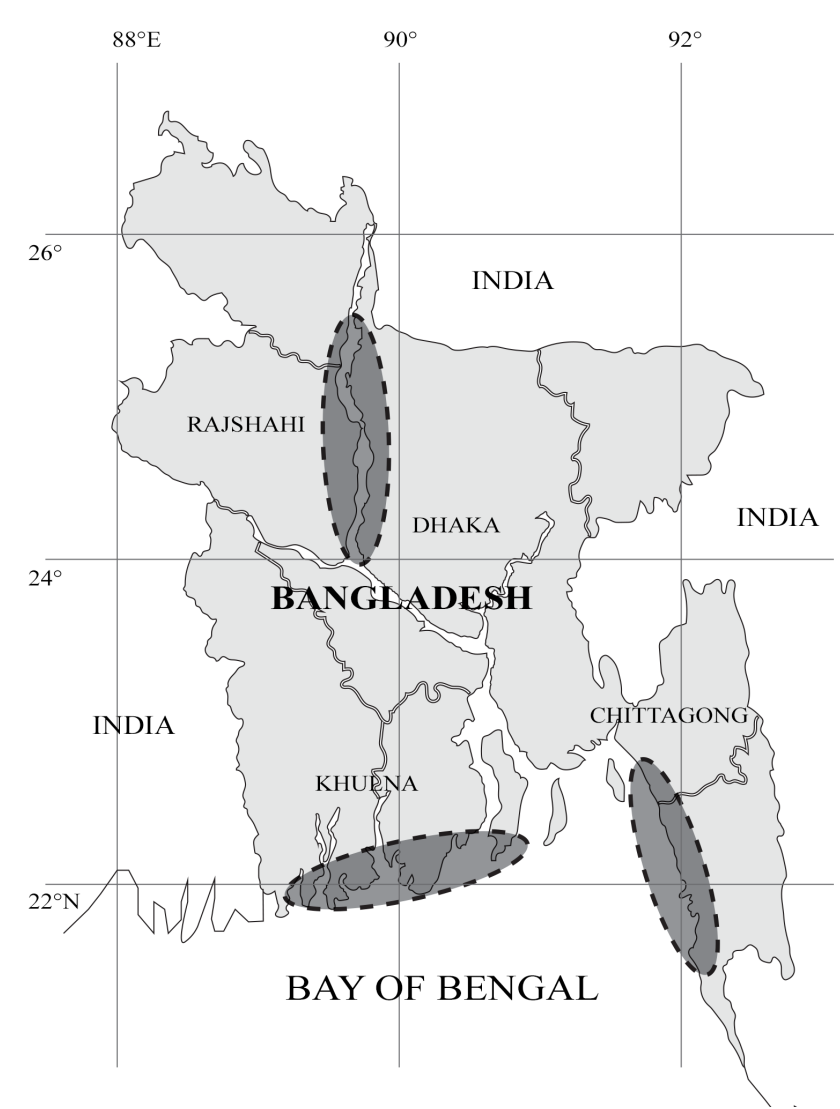

Fig. 2: Bangladesh map showing the potential areas for heavy minerals 

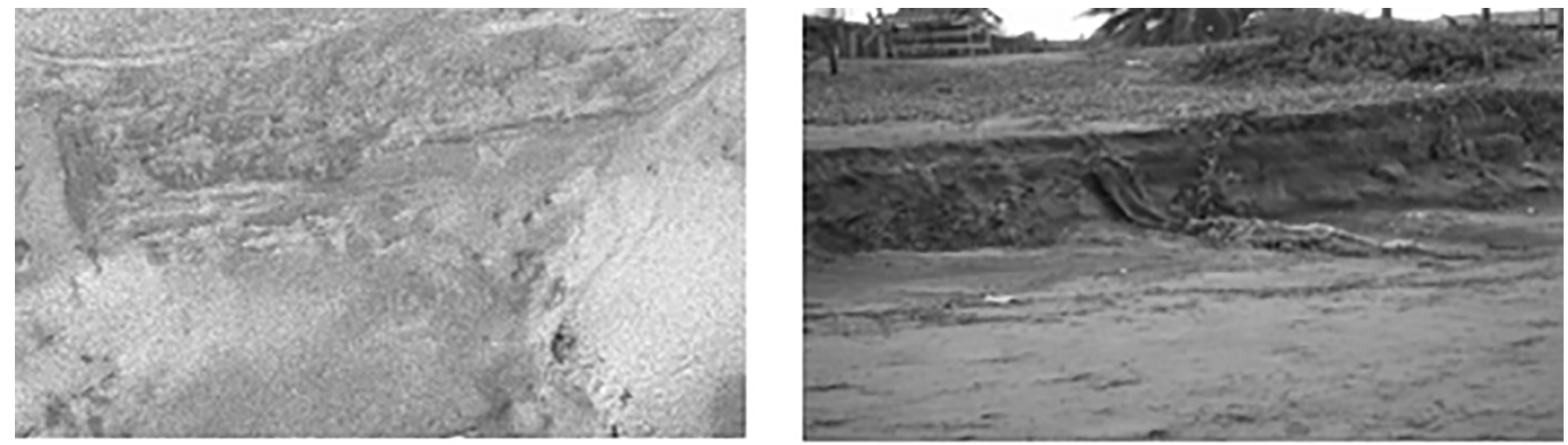

Fig. 3: Heavy mineral deposition at Teknaf and Silkhali of SE coastal area

of $3 \mathrm{~km}$ inland from the present shoreline. Total heavy mineral percentage varies from deposit to deposit ranging from $7.30 \%$ to $42.20 \%$; and on average these deposits contain $23 \%$ heavy minerals.

These heavy mineral deposits are mostly fine to very fine grained $(0.075 \mathrm{~mm}$ to $0.15 \mathrm{~mm})$. In total, these mineral sand deposits contain 4.35 million tonnes of heavy minerals among which 1.76 million tonnes are potentially economic minerals, which include ilmenite 1,025,000 tonnes, magnetite 81,000 tonnes, zircon 158,000 tonnes, garnet 223,000 tonnes, rutile 70,000 tonnes, leucoxene 97,000 tonnes, Kyanite 91,000 tonnes and monazite 17,000 tonnes. Reserves of economic heavy minerals altogether are depicted in Fig. 4. The minerals have the size range from 0.25 to $0.075 \mathrm{~mm}$. The grain size varies significantly from one deposit to another deposit. However, in all the deposits the grain size of zircon, magnetite and monazite is always finer $(0.075-0.11 \mathrm{~mm})$ than that of kyanite, garnet, ilmenite and rutile $(0.11-0.15 \mathrm{~mm})$. Mineralogical analyses of the heavy fractions of the beach mineral sand deposits have established that the average percentage of the important heavy minerals as zircon $4.20 \%$, rutile $2.04 \%$, ilmenite $26.03 \%$, garnet $6.45 \%$, kyanite $3.92 \%$, leucoxene $2.30 \%$, magnetite $1.87 \%$ and monazite $0.31 \%$. The average distribution of the economic heavy minerals (in \%) are shown in Fig. 5.

Mineral sand processing on the bulk samples from heavy mineral sand deposits has been carried out at the pilot plant of BAEC at Cox's Bazar to determine the separation characteristics of individual minerals taking advantages of the differences in properties like specific gravity, magnetic susceptibility and electrical conductivity using gravity (Spiral and Shaking table) magnetic and high tension separators. Flow chart of pilot plant studies are shown in Figs. 6 and 7.

Ilmenite and magnetite are separated successfully in the pilot plant with desired purity. Zircon, rutile and garnet are separated with more or less $90 \%$ purity. Some of the heavy

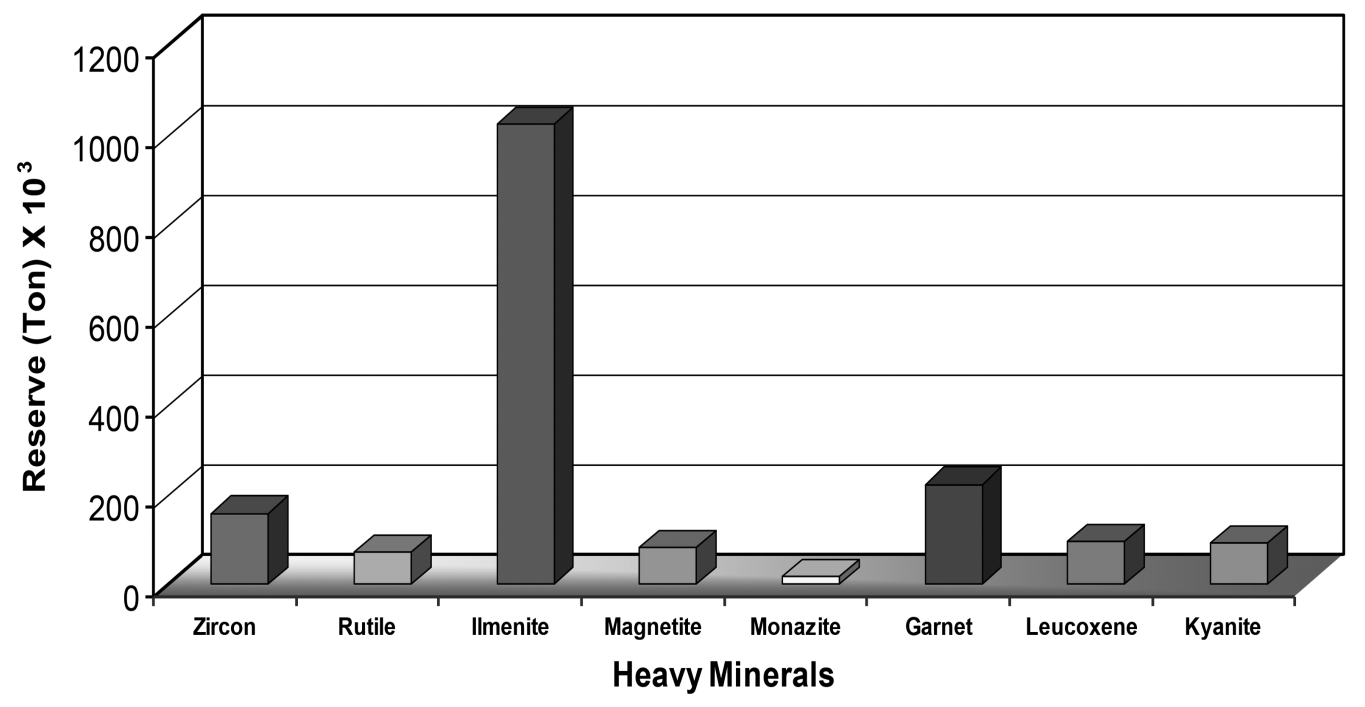

Fig. 4: Total heavy mineral reserves 


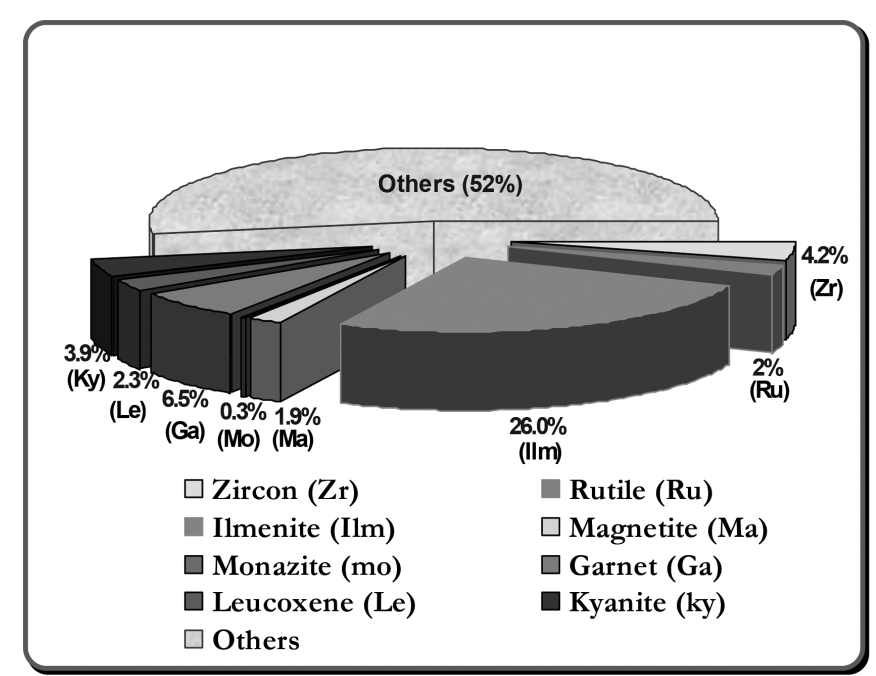

Fig. 5: Individual economic heavy mineral \% in total heavy fractions (Based on BAEC estimation) mineral products separated at the pilot plant are chemically analysed (Table 1). $\mathrm{ZrO}_{2}$ in zircon is around $65 \%$, which is quite satisfactory in respect of commercialization. An important value addition activity for the zircon concentrates is dry grinding of the zircon concentrates to zirflour for its application as an opacifier in ceramic industries. In Bangladesh there is a high demand for zirflour.

Though the desired physical grade is achieved for ilmenite, its chemical characteristics are not favourable. Ilmenite contains low level of titanium dioxide (around 43\%) and higher level of iron and chromium which fails to meet the industrial demands. As ilmenite is the most dominant constituent in the beach placer deposits, extensive research and development works are to be carried out to upgrade ilmenite through different beneficiation processes like oxidation - reduction, leaching and smelting which add substantial value to ilmenite by upgrading the low value titanium mineral into a high value product, synthetic rutile - a much sought after value added feedstock for the production of pigment. $\mathrm{TiO}_{2}$ in rutile is around $90 \%$ and in

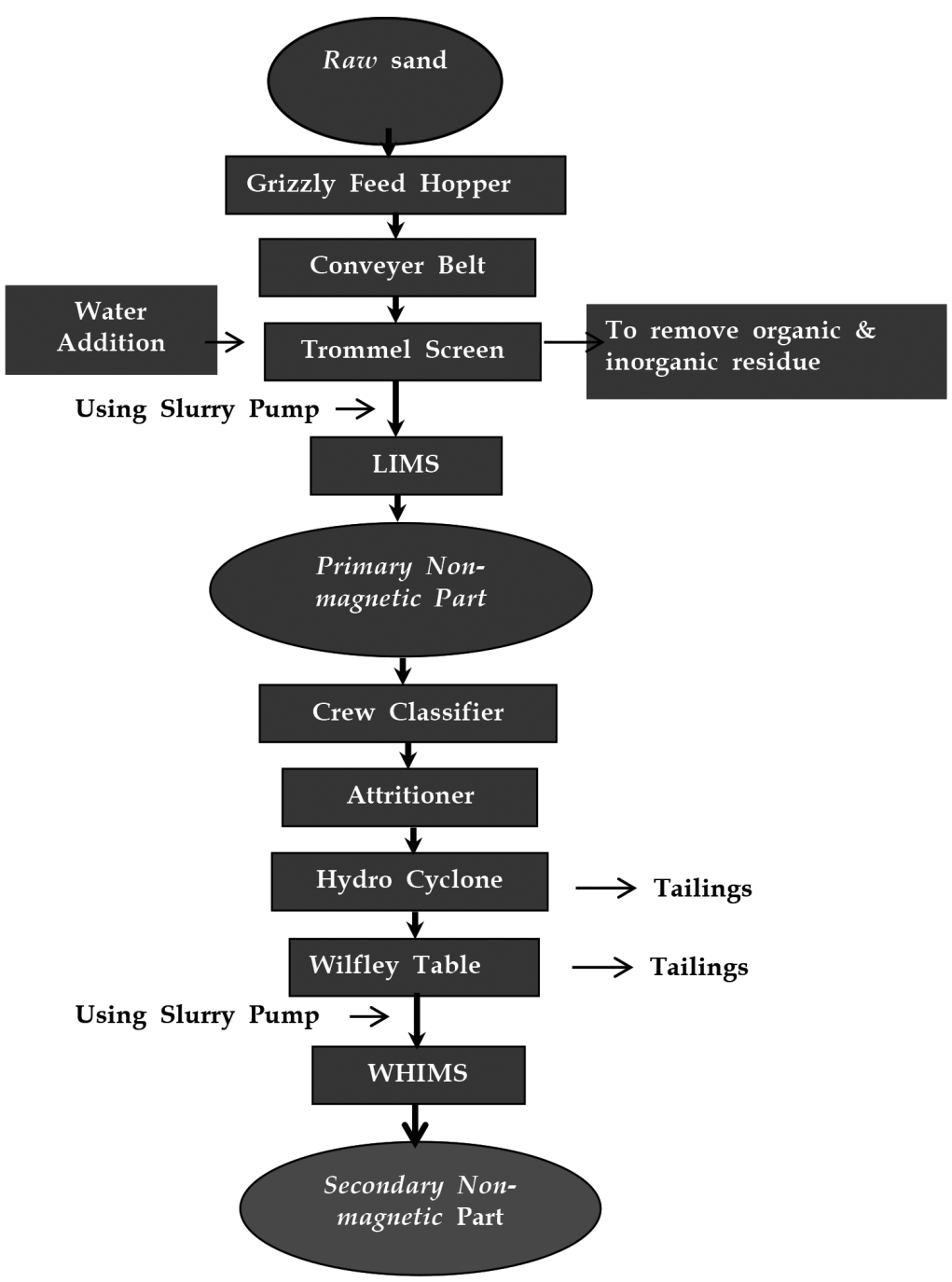

Fig. 6: Flow chart of pilot plant wet section 


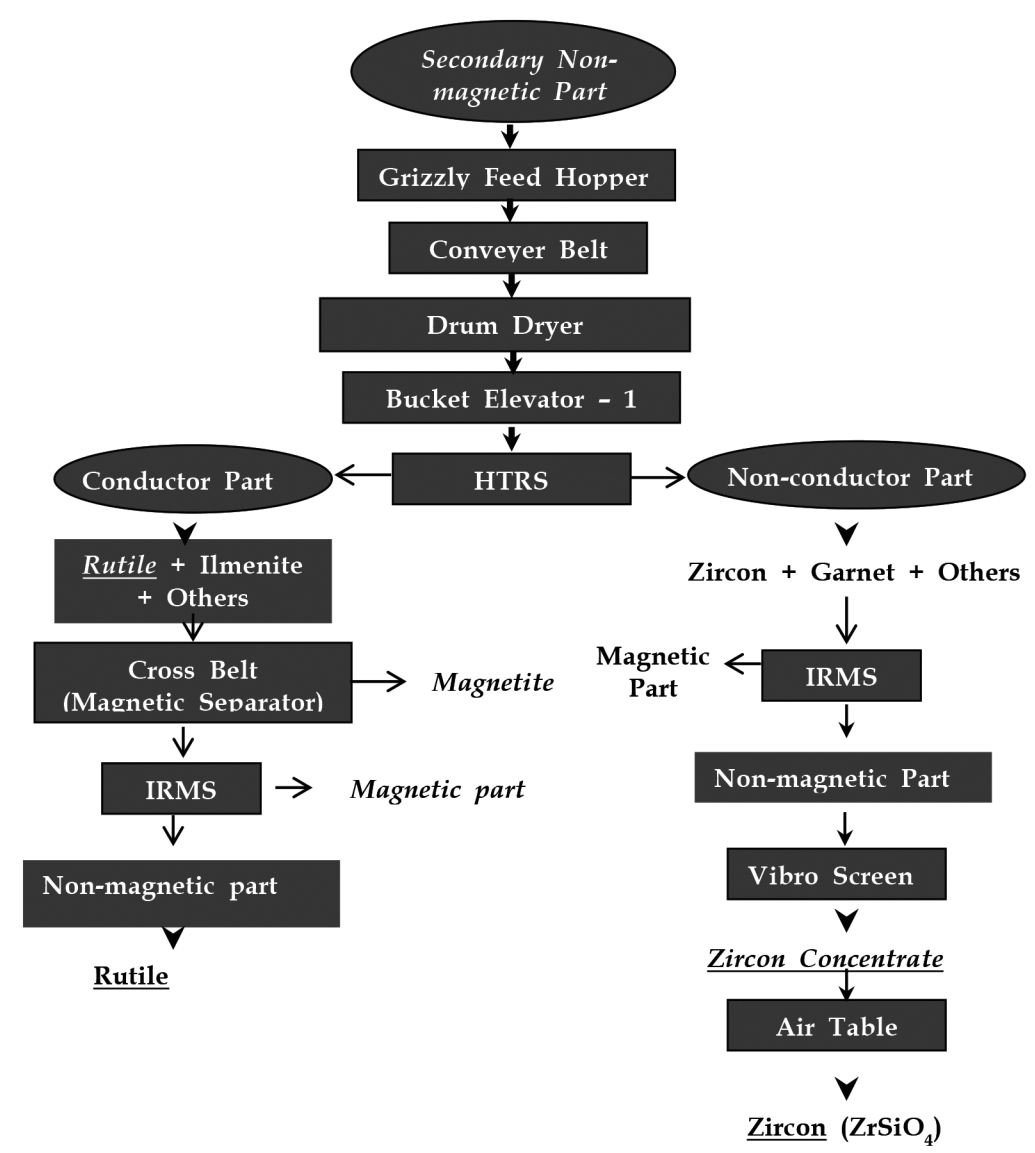

Fig. 7: Flow chart of pilot plant dry section

commercial grade it needs to be more than $90 \%$. Undesirable silicon content is higher. The upgrading of ilmenite and rutile will be required to make these minerals commercially viable. So far, more than 1500 tonnes of heavy economic minerals produced in the pilot plant have already been utilized by different industries of Bangladesh.

These valuable heavy minerals find extensive use throughout the world in different industries like pigment, paper, welding electrode, steel, ceramic, refractory, insulator, sanitary ware, abrasives etc. In addition, zircon and monazite are of direct interest to nuclear energy program. Zircon is used in its purest form to make nuclear fuel containers. Zirconium alloy is used as cladding for fuel rods in nuclear reactors but zircon is mainly used in the production of ceramic tiles, refractory and sanitary ware. Thorium metal from monazite has application in nuclear industry fuel assemblies. Rutile and ilmenite are the source of titanium oxide which are extensively used in pigment, paper and paint industries. Garnet is mainly used as abrasive material. Other heavy minerals also have large scale industrial applications.

\section{Other exploration programs}

Premier Minerals Limited (PML), a Singapore based International Mineral Development Company has been engaged in mineral sand exploration activities in Bangladesh since 2007. Extensive exploration activities were carried out in its licensed Badormokam-Shilkhali area of Teknaf under Cox's Bazar district

Table 1: Chemical analyses of a few separated heavy minerals

\begin{tabular}{llllllll}
\hline Elements & $\begin{array}{l}\text { Zircon } \\
(90 \%)\end{array}$ & Elements & $\begin{array}{l}\text { Rutile } \\
(90 \%)\end{array}$ & Elements & $\begin{array}{l}\text { Ilmenite } \\
(97 \%)\end{array}$ & Elements & $\begin{array}{l}\text { Garnet } \\
(90 \%)\end{array}$ \\
\hline $\mathrm{ZrO}_{2}$ & $65-66 \%$ & $\mathrm{TiO}_{2}$ & $90 \%$ & $\mathrm{TiO}_{2}$ & $43.37 \%$ & $\mathrm{Fe}_{2} \mathrm{O}_{3}$ & $27.80 \%$ \\
$\mathrm{SiO}_{2}$ & $30.6-32.8 \%$ & $\mathrm{ZrO}_{2}$ & $4-5 \%$ & $\mathrm{Fe}_{2} \mathrm{O}_{3}$ & $25.62 \%$ & $\mathrm{Al}_{2} \mathrm{O}_{3}$ & $24.80 \%$ \\
$\mathrm{Fe}_{2} \mathrm{O}_{3}$ & $0.18-1.1 \%$ & $\mathrm{Fe}_{2} \mathrm{O}_{3}$ & $5.9 \%$ & $\mathrm{FeO}$ & $29.75 \%$ & $\mathrm{TiO}_{2}$ & $2.48 \%$ \\
$\mathrm{TiO}_{2}$ & $0.13-0.9 \%$ & $\mathrm{SiO}_{2}$ & $1.45 \%$ & $\mathrm{SiO}_{2}$ & $1.20 \%$ & $\mathrm{Cr}_{2} \mathrm{O}_{3}$ & $1.45 \%$ \\
$\mathrm{~S}$ & $0.03 \%$ & $\mathrm{Al}_{2} \mathrm{O}_{3}$ & $0.40 \%$ & $\mathrm{P}_{2} \mathrm{O}_{5}$ & $0.03 \%$ & $\mathrm{CaO}$ & $0.25 \%$ \\
$P$ & $0.03 \%$ & $\mathrm{Nb}_{2} \mathrm{O}_{3}$ & $0.49 \%$ & $\mathrm{MnO}$ & $1.30 \%$ & $\mathrm{MnO}_{3}$ & $2.45 \%$ \\
& & $\mathrm{~S}$ & $0.02 \%$ & $\mathrm{Cr}_{2} \mathrm{O}_{3}$ & $0.57 \%$ & $\mathrm{SiO}_{2}$ & $35.80 \%$ \\
\hline
\end{tabular}


Table 2: Average particle size distribution of mineral sands of Silkhali-Badarmokam

\begin{tabular}{ccccccccc}
\hline Micron & 250 & 212 & 180 & 150 & 106 & 75 & 75 & $<53$ \\
\hline Average \% & 2.85 & 5.04 & 9.39 & 15.85 & 42.95 & 15.06 & 5.31 & 3.55 \\
\hline
\end{tabular}

Table 3: Fractionation of Badarmokam composite sample and XRF analyses of individual fraction

\begin{tabular}{|c|c|c|c|c|c|c|c|c|c|c|}
\hline Fraction & Mass\% & $\mathrm{TiO}_{2}$ & $\mathrm{ZrO}_{2}$ & $\mathrm{Fe}_{2} \mathrm{O}_{3}$ & $\mathrm{SiO}_{2}$ & $\mathrm{Al}_{2} \mathrm{O}_{3}$ & $\mathrm{Cr}_{2} \mathrm{O}_{3}$ & $\mathrm{MgO}$ & $\mathrm{P}_{2} \mathrm{O} 5$ & $\begin{array}{l}\mathrm{U}+\mathrm{Th} \\
(\mathrm{ppm})\end{array}$ \\
\hline HS Mag & 8.49 & 21.80 & 0.27 & 74.70 & 2.09 & 0.89 & 0.71 & 0.39 & 0.04 & 19 \\
\hline Mag 1 & 44.54 & 17.30 & 0.21 & 37.60 & 22.40 & 12.50 & 1.23 & 2.57 & 0.20 & 396 \\
\hline Mag 2 & 32.66 & 6.93 & 1.76 & 15.00 & 34.80 & 20.70 & 0.57 & 3.54 & 0.57 & 1273 \\
\hline $\begin{array}{l}\text { Non-mag } \\
+150 \text { Mic. }\end{array}$ & 4.51 & 25.40 & 4.24 & 1.61 & 30.10 & 24.30 & 0.04 & 0.66 & 2.56 & 217 \\
\hline $\begin{array}{l}\text { Non-mag - } \\
150 \text { Mic. }\end{array}$ & 9.80 & 23.30 & 36.30 & 0.76 & 26.30 & 5.22 & 0.04 & 0.16 & 1.56 & 1309 \\
\hline Total (Calc) & 100.00 & 15.25 & 4.44 & 28.14 & 25.45 & 14.01 & 0.80 & 2.38 & 0.55 & 732 \\
\hline
\end{tabular}

covering 7986 hectares which included electrical resistivity survey, shallow seismic refraction survey, hand flipping drilling and percussion drilling in a grid pattern. More than 800 percussion drillings were carried out to a depth of 3-24 m having average bore-hole depth $10 \mathrm{~m}$. A total of 739 lithologic logs were prepared reflecting the subsurface conditions of the areas and a total number of 9980 samples were collected which were subjected to various tests and analyses. Requisite number of representative samples were analysed and tested in the reputed laboratories of Bangladesh and in the Australian advanced laboratories belong to CRL, Auspac, AML and Titanatek Pty Ltd. Mineral sands of these explored areas are very fine to fine grained. Average particle size distribution of mineral sands of Badormokam-Shilkhali is shown in Table 2 (PML 2012). Heavy Mineral varies from 15-31\%. Fractional distribution of the composite samples from Badormokam and Shilkhali deposit along with the XRF analyses of respective individual fraction is shown in Tables 3 and 4 (PML 2012). Fractions of valuable minerals can be identified through the interpretation of the chemical data.

Based on exploration activities PML has ascertained significant resource of valuable heavy minerals such as zircon -185000 tonnes, rutile -52000 tonnes, garnet -150000 tonnes. It has also assessed other heavy minerals like ilmenite, magnetite, monazite, etc. It is evident from the mineralogical analyses of
Badormokam-Shilkhali mineral sand samples that the heavy fractions contain zircon $4.95 \%$, rutile $4 \%$, Ilmenite $16 \%$, leucoxene $7.15 \%$ and magnetite $6.45 \%$. Having carried out a feasibility study, PML has submitted an Exploitation/Mining Scheme to Bureau of Mineral Development (BMD), Bangladesh; to develop mineral sands resources from some of the selected mining blocks having 3210 hectares land of its licensed areas. PML has not yet been awarded the Mining Lease due to apprehension of negative environmental impact. PML is still desirous to exploit the heavy mineral resources sustainably complying the rules and regulations of the Department of Environment and taking proper mitigation measures as being practiced internationally to avoid environmental degradation. Based on current reserves, PML plans to establish a small commercial plant having 400 tonnes per hour capacity which will initially have a plant life of 10 years. However, plant life can be increased up to 20 years when adjacent areas will be available for exploration and mining.

PML has also carried out preliminary reconnaissance survey in a number of Bay of Bengal islands in the southern part of Bangladesh under Bhola and Patuakhali districts. Collected surface sample from Dhal Char contains 43\% $\mathrm{HM}$ and the sample from Vashar Char contains 50\% HM on average (PML, 2013). PML is desirous to carry out detailed study to assess the potentiality of these islands in respect of heavy minerals.

Table 4: Fractionation of Silkhali composite sample and XRF analyses of individual fraction

\begin{tabular}{lllllllllll}
\hline Fraction & Mass\% & $\mathrm{TiO}_{2}$ & $\mathrm{ZrO}_{2}$ & $\mathrm{Fe}_{2} \mathrm{O}_{3}$ & $\mathrm{SiO}_{2}$ & $\mathrm{Al}_{2} \mathrm{O}_{3}$ & $\mathrm{Cr}_{2} \mathrm{O}_{3}$ & $\mathrm{MgO}$ & $\mathrm{P}_{2} \mathrm{O} 5$ & $\begin{array}{c}\mathrm{U}+\mathrm{Th} \\
(\mathrm{ppm})\end{array}$ \\
\hline HS Mag & 4.40 & 22.10 & 0.37 & 64.10 & 7.66 & 2.59 & 0.91 & 0.87 & 0.09 & 55 \\
Mag 1 & 45.21 & 7.53 & 0.15 & 24.80 & 33.50 & 17.20 & 0.57 & 4.26 & 0.14 & 293 \\
Mag 2 & 36.16 & 7.65 & 0.82 & 12.80 & 28.30 & 19.00 & 0.13 & 4.00 & 0.33 & 342 \\
Non-mag & 4.28 & 14.70 & 1.16 & 1.41 & 40.50 & 26.40 & 0.03 & 0.83 & 3.11 & 93 \\
+150 Mic. & & & & & & & & & & \\
Non-mag - & 9.95 & 26.50 & 10.20 & 1.09 & 34.50 & 10.50 & 0.03 & 0.38 & 3.80 & 442 \\
$\begin{array}{l}\text { 150 Mic. } \\
\text { Total (Calc) }\end{array}$ & 100.0 & 10.41 & 1.45 & 18.83 & 30.88 & 16.94 & 0.34 & 3.48 & 0.70 & 307 \\
\hline
\end{tabular}


Recently, titanium rich HM deposit containing valuable heavy minerals at Brahmaputra River Basin has been reported (Rahman et al., 2014). Ilmenite from Brahmaputra Basin is found to contain up to $52 \% \mathrm{TiO} 2$ which is higher compare to the ilmenite of coastal beach. On an average, total heavy mineral percentage of the Brahmaputra-Jamuna sand bars is $8.92 \%$ (Akon, 2018).

\section{Radiation in heavy mineral sand deposits}

Higher radiation level is observed in many mineral sand deposits of the world which is mainly due to the presence of $\mathrm{U}, \mathrm{Th}$, and other radionuclides. People live in the deposit areas are exposed to higher radiation which may be hazardous to their health. Exposure to radiation is harmful for the public health and occupational workers if the radiation level exceeds the permissible dose. A number of radiation surveys were conducted by the scientists of BAEC in the mineral sand deposits. The average radiation dose rate in the sea beach area due to the natural radionuclides is $52.3 \mathrm{nGy} \mathrm{h}^{-1}$ (Alam et al., 1999) which is considered safe as per UNSCEAR (1988). The absorbed dose rates due to the radionuclides in heavy mineral concentrates in the pilot plant of Cox's Bazar varied in the range of .05-13.0 $\mathrm{iGy} \mathrm{h}^{-1}$ with an average of $4.30 \mathrm{iGy} \mathrm{h}^{-1}$. The average dose rate corresponds to annual average effective dose of $4.38 \mathrm{mSv}$ (Alam et al., 1999). The permissible dose for occupational workers is $20 \mathrm{mSv} \mathrm{y}^{-1}$ (20 millisievert per year) but for the general public it is only 3.5 millisievert per year. In some locations of Cox's Bazar deposit areas 30-50 millisievert radiation dose per year were observed which is much higher than the permissible legal limit. Zaman et al. (2012) determined the activity concentrations of bulk mineral sand samples of Cox's Bazar and separated mineral fractions. They observed activity concentration of U$238\left(\mathrm{~Bq} \mathrm{~kg}^{-1}\right)$ as $14849 \pm 751$ in separated zircon.

The uranium content of minerals such as zircon, monazite, etc. is a key parameter in the economics of mineral sand production as high uranium contents may significantly down grade the value of the mineral sand product (Duddy and Kelly, 1999). The presence of uranium is not considered a problem until its content is greater than 500 ppm. More than 500 ppm (U+Th) is observed in some separated fractions of Badarmokam mineral sand deposits (PML, 2012). In production phase uranium content of various products can be monitored to adjust processes to separate desirable low-uranium mineral populations and to maximise quality of the refined product of commercial grade.

\section{CONCLUSIONS}

The exploratory efforts of Bangladesh Atomic Energy Commission (BAEC) at the beaches and off shore islands in the south eastern coastal belt of Bangladesh has established seventeen (17) Êhigh grade heavy mineral sand deposits containing about two million tonnes economically important heavy minerals namely ilmenite, zircon, rutile, leucoxene, kyanite, garnet, magnetite and monazite. Premier Minerals
Limited also established significant heavy mineral resources in Teknaf area and submitted exploitation scheme for commercial development of heavy mineral resources of Bangladesh. Due attention has not been given yet by the government agencies for the development of these heavy mineral resources of Bangladesh in spite of their huge economic potentialities.

There are many instances of beach mineral sand mining for years together in the similar beaches of other countries without any major damage on the stability of the beaches and coastal zone since the replenishment of sand along the beach is a regular process.

Bangladesh also should go forward to mine these heavy mineral resources taking proper mitigation measures for environmental, ecological and social impacts. Only the desirable part of the mineral sand deposits will be mined. More than 80 percent of the sands will be backfilled. If required certain amount of sand can be dredged from the nearby sea basin for immediate reclamation.

Our neighbouring country India is extracting and developing heavy mineral sand resources of Orissa, Tamil Nadu and Kerala discovered along the coastal beaches of Bay of Bengal and Indian Ocean.

It is not desirable that these mineral resources will not be developed apprehending environmental impact; and thus losing an opportunity to utilise these heavy mineral resources for the significant economic benefit of the country.

Proper radiation monitoring programmes should also be taken up by the authority concerned to ensure the safety of public health due to the high radiation exposure. Development of the heavy mineral resources of Bangladesh will certainly contribute considerably towards economic growth, employment generation and establishment of mineral based industries. Further studies and extensive collaborative research activities need to be carried out for upgrading of low quality minerals and to satisfy physical and chemical requirements of end-users.

\section{ACKNOWLEDGEMENTS}

The author worked at Beach Sand Mineral Exploitation Centre and Nuclear Minerals Unit of Bangladesh Atomic Energy Commission (BAEC), Bangladesh for 32 years. Most of the investigations were done during his BAEC service and he is highly obliged to the BAEC authority for providing necessary facilities to carry out the investigations. The author is thankful to his colleagues particularly the geologists of BAEC for their assistance and help during field, laboratory and pilot plant studies. Heavy mineral investigation was also supported by Premier Minerals Limited. Thanks are also due to PML, particularly Mr. Craig Figtree for his help with regard to the work. 


\section{REFERENCES}

Akon, E. and Hossain, A.T.M. S., 2004, Prospect of Mineral Sand Deposits of Bangladesh. Abstract, 32nd International Geological Congress, Aug. 20-28, 2004, Florence, Italy.

Akon, E., 2015, Status of Mineral Sand Resources of Bangladesh: Prospect and Challenges for its Development. Recent Advances in Mineral Development and Environmental Issues. Das, M., Singh, P., Sahoo, H. K., Mohapatra, B. K., and Faruque, B. M. (eds.). Capital Publishing Company, New Delhi, India, pp. 77-92.

Akon, E., 2018, Findings of IRSM-BD Project titled Identification and Economic Assessment of the Valuable Minerals in the River sands of Bangladesh (IRSM-BD), Annual Report submitted to Geological Survey of Bangladesh, 35p.

Alam, M. N., Chowdhury, M. I., Kamal, M., Ghose, S., Islam, M. N., Mustafa, M. N., Miah, M. M. H., and Ansary, M. M., 1999, The 226Ra, 232Th, 40K activities in beach sand minerals and beach soils of Cox,s Bazar. Bangladesh. Journal of Environmental Radioactivity, v. 46, pp. 243-250.

Biswas, M. A. B., 1983, Heavy Mineral Variability in foreshore sediments of Teknaf- Inani Beach of Chittagong. Nuclear Science and Applications, Series-B. v. 14 and15, pp. 88-95.

Duddy, J. R. and Kelly, P. R., 1999, Uranium in mineral sands. Australian Institute of Geoscientists Bulletin, No. 26.

Howarth, W. J., Allen, D. W., Spry, A. H., and Moeskops, P. J., 1977, Amdel Report, No. 1168, Mineral Sands Study, Cox's Bazar, Bangladesh. The Australian Mineral
Development Laboratories, Frewville, South Australia, 81p.

Kabir, M. Z., Deeba, F., Rajib, M., Karim, M. M., and Zaman, M. M., 2010, Radioactivity and heavy mineral concentration at Coxs Bazar beach area, Bangladesh. Beach Sand Minerals Exploitation Center, Cox's Bazar, Bangladesh. BSMEC/TR-1/Dec-2010, 16p.

Macdonald, E. H., 1976, Final Project Report, Cox's Bazar Pilot Plant Project, Bay of Bengal Bangladesh; for the BAEC and the Australian Development Assistance Agency. $175 \mathrm{p}$.

PML, 2012,Technical Report. Premier Minerals Limited (Singapore).76p.

PML, 2013, Bangladesh Heavy Minerals Project. Premier Minerals Limited. 46p.

Rahman, M. A., Pownceby, M. I., Haque, N., Bruckard, W. J., and Zaman, M. N., 2014, Characterisation of titaniumrich heavy mineral concentrates from the Brahmaputra River basin, Bangladesh. Applied Earth Science (Trans. Inst. Min. Metall. B), v. 123 (4), pp. 222-233.

United Nations Scientific Committee on the Effects of Atomic Radiation (UNSCEAR), 1988, Exposures from natural Sources of radiation, Report to the General Assembly, U. N., New York, USA.

Zaman, M., Schubert, M., and Antao, S., 2012, Elevated radionuclide concentrations in heavy mineral-rich beach sands in the Cox's Bazar region, Bangladesh and related possible radiological effects. Isotopes in Environmental and Health Studies. V. 48 (4), pp. 512-525. 